\title{
Environmental communication for the rice field conservation in Semende Darat Tengah, South Sumatra
}

\author{
Yenrizal \\ Universitas Islam Negeri Raden Fatah, Palembang, Indonesia
}

\begin{abstract}
Depreciation of paddy fields has become a common phenomenon due to the conversion of land functions from agriculture to non-agriculture. The reasons are due to economic factors, settlement development, or policy. In the Semende Darat Tengah of South Sumatra, the paddy fields remain, and even the areas are expanding. This study aims to identify and understand how environmental communication mechanisms are applied in local communities, especially in Semende Darat Tengah, South Sumatra, to preserve the existence of rice fields. Methodologically, this study was conducted through communication ethnography. The authors live and interact with the community and research environment. Data analysis is carried out during the research process by combining the ethical elements of the study. This study indicates that the ongoing environmental communication mechanism is based on knowledge and understanding of the prevailing customary order and knowledge of local physical conditions. This knowledge undergoes an internalization that occurs continuously, from the ancestor eras, since the settlement was formed. The internalization process can be seen from listening, comprehending, and performing activities that become a shared perception of the rice fields and the local environment. This internalization takes place in a variety of natural environmental communication settings. The three main aspects that build people's perceptions are knowledge of the nuclear family level, interactions with neighbors and other communities, and the preserved traditional institutions.
\end{abstract}

Keywords: Kommunication ethnography, environmental communication; rice fields; Semende; local values

\section{Pelestarian sawah dalam perspektif komunikasi lingkungan di Semende Darat Tengah, Sumatera Selatan}

\section{ABSTRAK}

Penyusutan lahan sawah sudah menjadi fenomena umum yang disebabkan karena adanya alih fungsi lahan dari pertanian ke non-pertanian. Berbagai alasan yang biasanya muncul adalah karena faktor ekonomi, pengembangan pemukiman, ataupun kebijakan. Di Semende Darat Tengah, Sumatera Selatan, lahan sawah justru tetap bertahan dan bahkan terindikasi bertambah luas. Penelitian ini bertujuan untuk mengetahui dan memahami bagaimana mekanisme komunikasi lingkungan yang diterapkan di masyarakat lokal, khususnya di Semende Darat Tengah, Sumatera Selatan, dalam rangka melestarikan keberadaan sawah. Secara metodologi, kajian ini dilakukan secara kualitatif dengan metode etnografi komunikasi. Peneliti bermukim dan berbaur dengan komunitas serta lingkungan penelitian. Analisis data dilakukan selama proses penelitian berlangsung dengan memadukan unsur etik dan emik penelitian. Hasil penelitian ini menunjukkan bahwa mekanisme komunikasi lingkungan yang berlangsung berbasis pada pengetahuan dan pemahaman tentang tatanan adat yang berlaku serta pengetahuan tentang kondisi alam setempat. Pengetahuan ini mengalami proses internalisasi yang berlangsung secara terus menerus, mulai dari jaman nenek moyang, terbentuknya pemukiman, hingga saat ini. Proses internalisasi tersebut tampak dari kegiatan melihat, mendengar dan melakukan yang kemudian menjadi persepsi bersama tentang sawah dan lingkungan setempat. Internalisasi ini berlangsung dalam berbagai seting komunikasi lingkungan yang berlangsung alamiah. Tiga aspek utama yang membangun persepsi masyarakat adalah pengetahuan tingkat keluarga inti, melalui interaksi dengan tetangga dan masyarakat lain, serta kelembagaan adat yang terus terjaga.

Kata-Kata kunci: Etnografi komunikasi; komunikasi lingkungan; sawah; Semende; nilai lokal

Korespondensi: Dr. Yenrizal, M.Si, Universitas Islam Negeri Raden Fatah Palembang, Jl KH Zainal Abidin Fikri Km.3,5 Palembang, email: yenrizal_uin@radenfatah.ac.id 


\section{INTRODUCTION}

The reduction of rice fields in Indonesia is a critical issue. Data from the Central Statistics Agency (BPS) in 2019 noted that the existing paddy fields were only around 7.4 million hectares, whereas, in 2013, it was still by 7.73 million hectares. Meanwhile, for South Sumatra, which in 2002 had declared as a national food barn, the number of paddy fields underwent a decline in the 2008-2012 range of 5,782 hectares. Generally, this shrinkage occurs in the swamps and tidal areas (BPS, 2020).

In detail, BPS South Sumatra releases that rice fields in South Sumatra based on land use is $819,116 \mathrm{Ha}$. This amount is divided into 4 (four) typologies of land, namely, irrigation covering an area of 111,253 Ha, rain-fed $(106,709 \mathrm{Ha})$, tidal $(255,087 \mathrm{Ha})$, and swampy land (346.061 Ha). Meanwhile, based on the Planting Index (IP), the area of rice fields in South Sumatra consists of 1 planting area of 486,771 Ha, two plantings of $138,795 \mathrm{Ha}$, three plantings of $21,012 \mathrm{Ha}$, while the fields that are not planted are 135,320 Ha and TDP 37,218 Ha (BPS, 2020).

These data show that the number of paddy fields in South Sumatra, as one of the mainstay areas of food crops in Indonesia, is facing a reduction. The decrease is caused strongly by the conversion of land to non-agricultural activities. Therefore, it has a significant impact on the food security program launched by the government (Arif et al., 2020).

Explaining the issue of land conversion is related to the community's system concerning the mechanism of rice farming. The changes in land used by the community are generated by numerous causes, particularly economic reasons. It is mainly because the rice fields are run by the community themselves, not by companies or investors, as it is commonly found in other plantation sectors. Knowledge regarding the rice field system, including sociocultural and economic orders, is essential to describe the problems.

Many studies and facts show that land conversion occurs every year with an increasing area. On the island of Java, although this area is still the main rice supplier in Indonesia, the field loss continues to take place. Around 40,000 ha of paddy fields have been converted to other sectors (Ashari, 2016). Meanwhile, in the City of Tasikmalaya, changes in land use have been significant and indicate an increase continuously (Djoni et al., 2016). Several areas in South Sumatra also encountered the same circumstances, especially in the areas known as food barns and rice centers, like in Banyuasin Regency (Wijaksono \& Navastana, 2012).

In some cases, changes in the function of paddy fields are caused by the factors of economy and policy (Kusumastuti et al., 2018). Economic parts are due to the community's need to find resources with other methods. This usually appears because the fields are unproductive or the harvests are unsatisfactory. Meanwhile, the policy aspect is due to government programs, such as constructing new cities, offices, and others. These then have implications for the narrowing of paddy fields, which affects rice production.

The conversion function of paddy fields is related to the changing pattern of agriculture in Indonesia. The rice field method was originally a system of using high internal inputs or maximizing substances from within. This is seen from using local rice, organic fertilizers, irrigation systems, and agricultural products. Crucial problems then emerged after the industrialization of the agricultural sector, especially the emergence of the idea of a green revolution, which damaged local institutions and at the same time changed the people's perspectives on their traditional agricultural system (Rinardi et al., 2019). Farmers finally compete to pursue economic advantages or boost their rice production. This is known as the "five-farming-system" program (Iskandar \& Iskandar, 2017).

Industrialization of the agricultural sector inevitably affects people's perceptions of agriculture. In some places, the mindset that previously viewed rice farming as an aspect attached to socio-cultural arrangements of the community has finally turned into an economic pragmatism. The crop yields are not only for food security but also to meet the growing needs of farmer's life. This way of thinking about commercial agriculture is indeed a policy choice and a logical consequence of the agricultural development programs (Yudiarini, 2011); (Mahmuddin, 2013). Commercial methods can indeed boost agricultural production. But these also weaken people's understanding of rice fields' philosophy. 
In this context, it can be seen that there is a tendency for changes in community farming patterns caused by a new point of view regarding the agricultural sector. This relates to socio-cultural aspects of the economy, policy, and unity in an ecological context. Human behavior and actions will affect the environment because it is a united system. Humans and the environment have a close relationship arrangement, especially in the flow of material, energy, and information (Rambo, 1983). This then forms a community perspective on the agricultural ecosystem, later manifested in their practices.

It can be said that efforts to conserve rice fields and avoid land conversion are closely linked to the community's perspective on the rice fields (Feintrenie et al., 2010). This point of view shows that there is a process of constructing a particular meaning of the community in looking at the environment and everything in it (Yenrizal, 2018). This field can be interpreted as an introductory study in environmental communication.

The idea of environmental communication emphasizes the reality that rice fields, with all their ecosystems, are an entity as a place for people to live and carry out their activities. Like studies conducted by many experts, Rice fields are an integral part of the community. Here, the rice fields undergo a process of meaning construction. In this sense, they are a symbol that owns a special significance for the community (Yenrizal et al., 2015). Therefore, this point shows an essential study in environmental communication.

In this study, it can be seen from references showing that environmental communication is a pragmatic and constitutive action for human understanding of the environment as well as individual relations with nature; it is a symbolic medium that people use in constructing environmental problems and negotiating society's different responses to the environment. In this case, there are two main functions of environmental communication, namely (1) pragmatic and (2) constitutive (Cox, 2012). These underline facts that the environment and humans are inseparable.

Referring to Cox and AT Rambo and the reality of rice fields in South Sumatra, it is essential to understand this issue deeply. The emphasis is on preserving rice fields in the community by prioritizing socio-cultural and economic approaches to form a distinct point of view. The assumption is that not all regions will be in the same condition pursuing economic interests from existing natural resources. Some areas do not put forward the purely economic aspect per se as its reasons. It can be ideological-historical reasons which include identity and community identity. It can also be due to natural conditions that are impossible. Or it is because of both (ideological-historical and natural factors).

This researchtakes the area ofSemendeDarat Tengah, part of Muara Enim Regency, South Sumatra, as a locus of the study. In this region, the existence of rice fields remains conserved, especially in South Sumatra, primarily in terms of land quantity. Characteristics of rice field cultivation using traditional (non-technical) irrigation and are strongly influenced by local habitual arrangements. There is a customary system that has a significant influence on land use activities in Semende. The custom, called Adat Bemeraje Anak Belai, has been practiced by the community for hundreds of years, where the essence of this custom is joint control of inheritance and management rights for the eldest daughter, called Tunggu Tubing (Yenrizal et al., 2015).

The research question here is how the people of Semende Darat Tengah carry out the mechanism of environmental communication to preserve the rice fields. The communication mechanism will be connected with various customary and social systems that develop in the community. Based on the research question, the objectives are to identify and understand the environmental communication procedures applied in local communities, especially in Semende Darat Tengah, South Sumatra, to conserve the existence of rice fields.

To answer the objectives above, Cox's (2010) and Flor (2004) ideas can be used as initial directives. If Cox emphasizes pragmatic and constitutive aspects as the main function of environmental communication(Cox, 2012), Flor highlights that environmental communication exists in the community's culture, has been inherent from the beginning, and often becomes a kind of local wisdom. Nature and culture are closely attached; both are not dichotomies but continuum; and environmental communication programs must support and be based on culture 
(Flor, 2004).

Flor's description will explain how the community understands their environment in the context of their culture, which then develops the conservation of rice fields. It is believed that environmental communication must take advantage of the processes of enculturation and the existence of indigenous peoples with their arrangements, including utilizing various modern communication technology devices. All must collaborate as one (Flor, 2004). In the case of the Semende Darat Tengah community with all their systems, especially in the use and conservation of rice fields, Flor's opinion has its relevance here.

\section{RESEARCH METHODS}

This research applies a qualitative approach with communication ethnography (Creswell, 2007) that sees community activities as a communication event. The case took place in the context of the speech community in Semende Darat Tengah, Muara Enim Regency, South Sumatra. The focus of this research takes not only a particular village but several villages randomly in the Semende Darat Tengah area. It considers that community characteristics, physical conditions, customary and social systems are practiced uniformly in all villages.

The study is done through direct observation (participant research) in the area for a month, interviews with six community members, and relevant literature. It took ten months of research with direct observation on the daily activities of the community. The focus is on communication events and settings that occur about rice field management in the research location. It is conducted randomly and targets areas and phenomena that are considered related to this research topic.

Data are analyzed by referring to the principles of qualitative research, in line with the characteristics of the communication analysis of ethnography, namely the examination of events, settings, and communication patterns. The inquiry starts from the data collection to writing research results. The data also undergo a review process regarding the emic and ethical aspects so that the rationality of the data can be confirmed. It is widely used, especially in aspects of local knowledge of the community.

\section{RESULTS AND DISCUSSIONS}

Semende Darat Tengah Subdistrict, Muara Enim Regency, South Sumatra, is a highland in the Bukit Barisan mountains. Its position is at the tip of the province of South Sumatra, directly adjacent to the province of Bengkulu. The altitude of the area reaches $1,040 \mathrm{~m}$ above sea level. So the weather is quite cold and dewy. The temperature is around 22-240 C. The sun does not shine as brightly as other low-lying areas, and the air tends to be humid. There are six villages in this sub-district, and all of them are one system of customary, social, livelihood, religious, and natural environmental conditions. All residents are homogeneous, coming from the Semende ethnicity.

Semende Darat Tengah Subdistrict was once a part of Semende Subdistrict until the territorial division was carried out into Semende Darat Tengah, Laut, and Ulu. All of them are a unit of the Semende ethnic group and have the same traces of origin. The terms of Tengah and Ulu refer to a higher area, while Laut refers to a lower area position.

The topography of the hilly area is the main character here. The locations are generally high hills and deep valleys. Moreover, it is tough to find a flat area. Most of the people here work in rice farming, coffee, vegetables, and other types of farming.

The main crops developed by the community consist of two categories, namely coffee and rice. This has become an identity and is embedded in the daily activities of the Semende people. It is mainly coffee, which has become a distinct identity for the Semende people and has been processed and marketed in various products. Other crops, such as vegetables, are generally only planted by residents as secondary meals that are not run en masse. About the last five years, some residents have tried to develop chili and tomato plantations in a fairly large number.

Coffee and rice are closely related to the long history of the Semende people. The Send is a fairly old ethnic group and has inhabited this area for hundreds of years. No one can confirm when the Semende community occupied this area, only from a few records that have been written about the history of Semende, it is stated that the history of the community is the history of the arrival of Islam to this location (Arifin et al., 2017). This is indeed widely discussed 
by various scholars who all mention that the history of Semende is related to the spread of Islam. Accordingly, the religion adopted by the Semende community is Islam (Yenrizal et al., 2015).

What is unique and closely related to the existence of rice fields is the presence of traditional institutions used by the community, commonly called the Bemeraje Anak Belai Custom, often also referred to as the Tunggu Tubing Custom (Velinda et al., 2018). The hallmark of this tradition is the high respect for land (rice fields and houses) as well as for the eldest daughter in a family. The eldest daughter is called Tunggu Tubing. This position is quite important because a Tunggu Tubing has the right to receive the family's inheritance and manage it. Inheritance property is only handed over to Tunggu Tubing, while other children who are not the eldest children do not get any rights. Tunggu Tubing does not obtain property rights, but only rights to manage or usufructuary rights. Automatically, inheritance managed by a Tunggu Tubing cannot be traded. This property remains a joint property, but the management and responsibility lie with the Tunggu Tubing (Mahdi, 2016).

In the location of this research, the actual number of rice fields varies. Each village has an area ranging from 30 ha to 200 ha. In Swarna Dwipe village, rice fields are around 30 ha owned by 20 families, while in Tenam Bungkuk Village, the rice fields are 150 ha owned by 130 families. Likewise, in other villages, such as Gunung Agung Village, the field reaches 90 ha. The difference in the area of this rice field is because there are several villages from the result of territorial division, which previously were farming locations for the surrounding community. For example, Tunggu Tubang of Swarna Dwipe are generally the residents in other villages, such as Tenam Bungkuk Village, Rekimai Jaya Village, Gunung Agung Village, Padang City Village. For the Semende Darat Tengah area itself, the rice fields are 1,219 ha (BPS, 2021). This rice field is $40 \%$ of the total area of the sub-district itself. While in fact, this area is also a center for coffee and vegetable gardens. Rice fields are a priority for agriculture with a constant area every year.

Rice field has its symbolic meaning. It is not only an economic plant whose results are traded. Here, the rice field is interpreted as a representation of prosperity as well as power, namely the power of Tunggu Tubing as a group that has the right to manage the fields (Yenrizal et al., 2015). Being a Tunggu Tubing is important where it is initially considered a very profitable position that certainly inherits rice fields and houses (Mahdi, 2016).

The rice fields then have a special treatment for the Semende community. These are an integral part of the integrity of the community environment, which makes it necessary to exist as long as the community endures. The firmness of this case can be seen clearly in this study, where rice fields are not only considered as aspects having economic value.

Interviews and observations have pointed out that rice fields have their position forming a certain meaning through a separate process. This process of meaning establishment starts from the nuclear family institution, extended family, a village community, and extends to the Semende community who live outside the area. It occurs in a separate communication mechanism through interpersonal approaches and other media (Yenrizal, 2017). The meaning built on the rice fields is a symbol of power and the identity of the Semende people as well. In this context, rice fields are not only about the economy but are related to the identity of the Semende people. There are no Semende people who do not have rice fields; that is a term that is frequently raised.

This study indicates that the formation of meaning about rice fields for the Semende community is through various mechanisms. The first step is socialization in the nuclear family (father, mother, child). This is where initial knowledge is obtained, where a child is accustomed to participating in rice field activities, beginning from the initial processing of the land to the harvest period. A child is always involved, and messages are constantly conveyed that rice fields must be protected, maintained, and owned together. Speech that often sounds is like words, "sawah kite nak dijage, dirurui. Sawah ini kele ka diurus oleh ayuk kaba, ayuk kaba tu tunggu tubang, jangan kaba ganggui, dide elok care Semende" (Our rice fields must be guarded, look after. This rice field will be taken care of by your older sister. Your sister is Tunggu Tubang, don't disappoint her, it is not good according to Semende custom).

The socialization in the nuclear family 
goes from a generation to another one. Parents have central roles in internalizing community values to their children. In the process, parents often encourage and demand their children be involved directly in cultivating their lands. This is a primary communication method where verbal and non-verbal aspects occur simultaneously. At a time, a child knows various techniques in farming and the importance of having an agricultural field. Here, a concrete example is a habit of storing crops in the barn (called Tengkiang in the Semende language). The presence of Tengkiang indicates that rice must be filed. Storing is for preparation if the crops are needed at any time, and these are not for sale. This Tengkiang can be found in each corner of Semende so that people can recognize it quickly. For the younger generation, the existence of Tengkiang brings an understanding that storing rice is highly required.

The second is imitating what the neighbors do. Because the community has identical customary order, all residents also practice it, namely relying on the Bemeraje Anak Belai system with the strength of the Tunggu Tubang institution. Everyone performs the same practice, so that knowledge gets more solid. It continues until they are teenagers, adults, having families and children, and so on.

This kind of relationship is because they live in adjoining houses in neighborly life and a larger community, that is, a village. As a rural society, they are used to meeting and gathering in the afternoon after working in their respective fields. Mainly, children are also used to playing and hanging out with friends in their village. The meeting places for residents are usually Kalangan (village market) once a week. Here, they usually meet all elements of the community who visits this market. The need is for not merely shopping but drinking coffee, talking with other residents as well. The spread of information is quite diverse and fluid. It includes information about rice fields and current environmental conditions. In sum, everything here can emerge and develop naturally.

Another gathering place is the sports arena. It is a distinctive feature of rural communities in South Sumatra, where residents are so happy in sports activities, especially volleyball. Generally, those who come here are young men. Usually, they are here once a week. While watching a volleyball match or waiting for their turn to play, residents are used to having conversations about anything. In this case, the volleyball court becomes a spot to spread information on the community, such as rice fields, coffee, damaged roads, crops, or other topics.

In addition to the village market and volleyball court, residents gather in houses of worship, especially during Friday prayers. On this day, all the males will return to the village for the Friday pray together. This is where the conversation usually takes place, before or after the pray. While waiting for the preacher to give a lecture, it becomes a habit for residents to assemble first.

Events such as wedding parties, aqiqah (Islamic tradition of sacrificing an animal on the occasion of a child's birth), or tahlilan (recitation of qur'anic verses) also act as a gathering place for the community. For the people of Semende, all traditional processes and rituals must be carried out in cooperation; nothing is done individually. The collaboration started from the planned activity to the cleaning of trashes in locations after the event ended. In this case, the occasions become a place for information exchange among residents.

At each location and gathering place, the communication setting is usually quite open, in the sense that anyone can participate. But this is also adjusted to the context of the event. For example, there are differences between the communication settings of males and females, the youth and the older groups. In certain events, the communication pattern of each group can be in one setting. However, it remains a limited case. Usually, it takes place in different circumstances.

Third, there are social provisions always emphasized by local stakeholders that rice fields may not be sold or converted to non-agricultural forms. The stipulations have become common knowledge, usually delivered at formal events, discussions in shops, fields, etcetera. The land is not allowed to be sold because it belongs to one big family. This further adds to the idea that rice fields are indeed a prime priority for the Semende community. The results of the rice fields are used for family food for a year until the following year's harvest. This term is commonly called subsistence in community agriculture.

The emergence of meaning about rice fields 
Table 1 The emergence of meaning about paddy fields and the environment in the community of Semende Darat Tengah

\begin{tabular}{ll}
\hline The Development of Meanings & Explanation \\
\hline $\begin{array}{l}\text { From the socialization of societal values and } \\
\text { tradition in the nuclear family }\end{array}$ & $\begin{array}{l}\text { The initial stage starts from Listening, } \\
\text { comprehending, and performing }\end{array}$ \\
$\begin{array}{l}\text { Duplicating the practices generally used by } \\
\text { neighbors }\end{array}$ & $\begin{array}{l}\text { Imitating neighbors' habits in social life by } \\
\text { examining and making }\end{array}$ \\
Customary provisions & $\begin{array}{l}\text { Customary rules are conveyed by family, } \\
\text { neighbors, Meraje and Tunggu Tubing }\end{array}$ \\
\hline
\end{tabular}

Source: Research analysis, 2020

and environmental conditions can be seen from the table 1 .

It can be seen in the table above that the development of meaning about environmental conditions in Semende Darat Tengah is a natural process. Three important elements -- the nuclear family, neighbors, the surrounding environment, and customary rules (by customary institutions) -- contribute critically to the establishment of the environmental meaning, including rice fields. The method of inheriting these meanings does not simply occur, but there is a mechanism for imparting knowledge to the next generation.

The development of the meaning of rice fields has a crucial influence on the integrity and sustainability of the fields in the Semende Darat community. The data mentioned above (1,219 ha) shows a relatively stable paddy field that now has even expanded since its inception. In this sense, a customary system has played a major role in the sustainability of rice fields in Semende Darat Tengah to this day.

The Meraje Anak Belai tradition used in Semende has relied on Meraje and Anak Belai as its central point. Merle is the mother's brother in a family. In other areas, it is known as Uncle, and the Semende people call it Meraje. This figure plays an important role, not Tunggu Tubing. Meraje is male, and Tunggu Tubang is female. The final decision in a family will always be discussed with Meraje's permission, including, for example, the choice to marry off a member of the family. In other words, there are customary institutions that remain influential and persist, whose system imposes marks on the community. Finally, these boundaries have a significant influence on the natural conditions they live in.

Merle is the highest communication actor in the Semende traditional order. Meraje must support any decisions related to the continuity of an extended family. There was a case where a Meraje moved to another domicile, and Tunggu Tubang wanted to ask someone else to work in her fields; she had to talk first and meet Meraje, who stayed outside the village.

In the context of, for example, a family member who will change the function of land to non-agriculture activities, Meraje places an important position in this matter. Even though Tunggu Tubing has the right to run the land, there must be consent from Meraje. Without his approval, the process cannot be carried out.

The strength of traditional institutions with the presence of Meraje and Tunggu Tubing is an essential factor in maintaining the ecosystem in Semende. As the main actor of communication in society, the meaning given by Meraje will usually be a reflection of the community. Informants in this study acknowledged that Meraje is the principal figure, and Tunggu Tubang acts as the executor in the field. Syaipul (52 years old), an informant in the study, confirms this fact. Although other communities have their rights, Meraje's permission on the rice fields is inescapable. It is because the rice fields in Semende are the lands collectively managed by Tunggu Tubing.

A Message in a certain position also becomes an integral part of society. $\mathrm{He}$ is the manager of rice fields, farms, and so on. He is also the husband of a Tunggu Tubing. In other cases, he is a Middle Child (the younger brother of Tunggu Tubing, usually the 2nd, 3rd, and 
so on). Therefore, the knowledge of a Meraje about environmental conditions in Semende is a decisive part. Hasan (58 years old) admits that, as Meraje, he must completely grasp the management and use of the lands. It often happens that rice fields are converted into coffee plantations. To some extent, this is permitted because it is still utilized for agricultural areas. But it must be a limitation in the conversions because coffee is a long-lived plant and will still reduce rice fields.

The threat to the possibility of land conversion is mainly because many Tunggu Tubangs move out from the village for several reasons (living with their husbands, working, studying, or continuing their formal education, and so on). This has an impact on the abandoned paddy fields. The unmanaged land then has the potential to be converted to other forms. Usually, this initiative comes from individuals outside Semende who want to establish a business in the area. It is in this matter that the roles of Meraje are essential. Even though Tunggu Tubing manages the land, it is still under Meraje's direction.

All of Meraje himself understands the relationship between the community and the environment from their active involvement in the Semende community. They were born and raised there. So they know the actual conditions of the area. Although some Meraje has moved out to new domicile, the relationship with Semende is still maintained, and traditional responsibilities are a duty that must be carried out. In his family institution, a candidate for Meraje is also familiarized with various teachings from his family about the Semende traditional system, the position of rice fields in people's lives, the status of Tunggu Tubing, and the place of Anak Belai (a nephew that Meraje must pay attention to). This socialization is usually received personally from their parents. In addition, the information also comes from seeing Meraje's activities in other families. In consequence, it develops as shared knowledge regarding the existence of Meraje.

The results of this study indicate that there are three ways to internalize knowledge in the Semende community, be it through a Meraje, Tunggu Tubing, or family about natural conditions and the prevailing customary system, namely listening, comprehending, and performing. Listening is a training stage in the family. Children will usually always be taught by their parents regarding the Meraje and Tunggu Tubing, the use of rice fields, coffee plantations, and houses. On the other hand, they will also be able to discern how the fields are farmed, how the water for the fields is distributed, how the crops are stored, when is the right time to plant, how to fertilize the land, and harvest. They will practice all of these matters when the day comes because a Meraje candidate is born and raised in Semende. Therefore, knowledge and understanding of the position and function of rice fields for the community are well understood.

In the context of communication, the internalization of knowledge about natural conditions, rice fields, and the position of a Meraje and Tunggu Tubang becomes the main basis for shaping perceptions. And perception itself is the core of communication (Zacks, 2019). The perception of a Meraje or Tunggu Tubing as well as other Semende residents is largely determined by how the internalization process (listening, comprehending, and performing) transpires. If it is fulfilled, everyone in Semende tends to have the same perception of rice fields and environmental conditions. These identical views thus lead to equal treatment for everyone. These Phenomena truly happen in Semende, especially in the location of the study. An illustration regarding the internalization of knowledge concerning environmental conditions and the establishment of public perceptions or the environmental communication mechanism in a broader description can be seen in the figure 1 .

This continuing process (listening, comprehending, and performing) is an environmental communication mechanism developed in Semende. The basis of all of this procedure is the customary system of Bemeraje Anak Belai so that all spreading information comes is filtered by the prevailing customary rule. This can be seen from the current conditions in 2021, where the Semende area has been easily accessible through roads and the access for communication is really good because of a proper connection for mobile telephone networks. But the most important thing is that rice fields and environmental conditions remain unchanged. Even if there is a transformation, it is not quite significant.

Listening, comprehending, and performing 


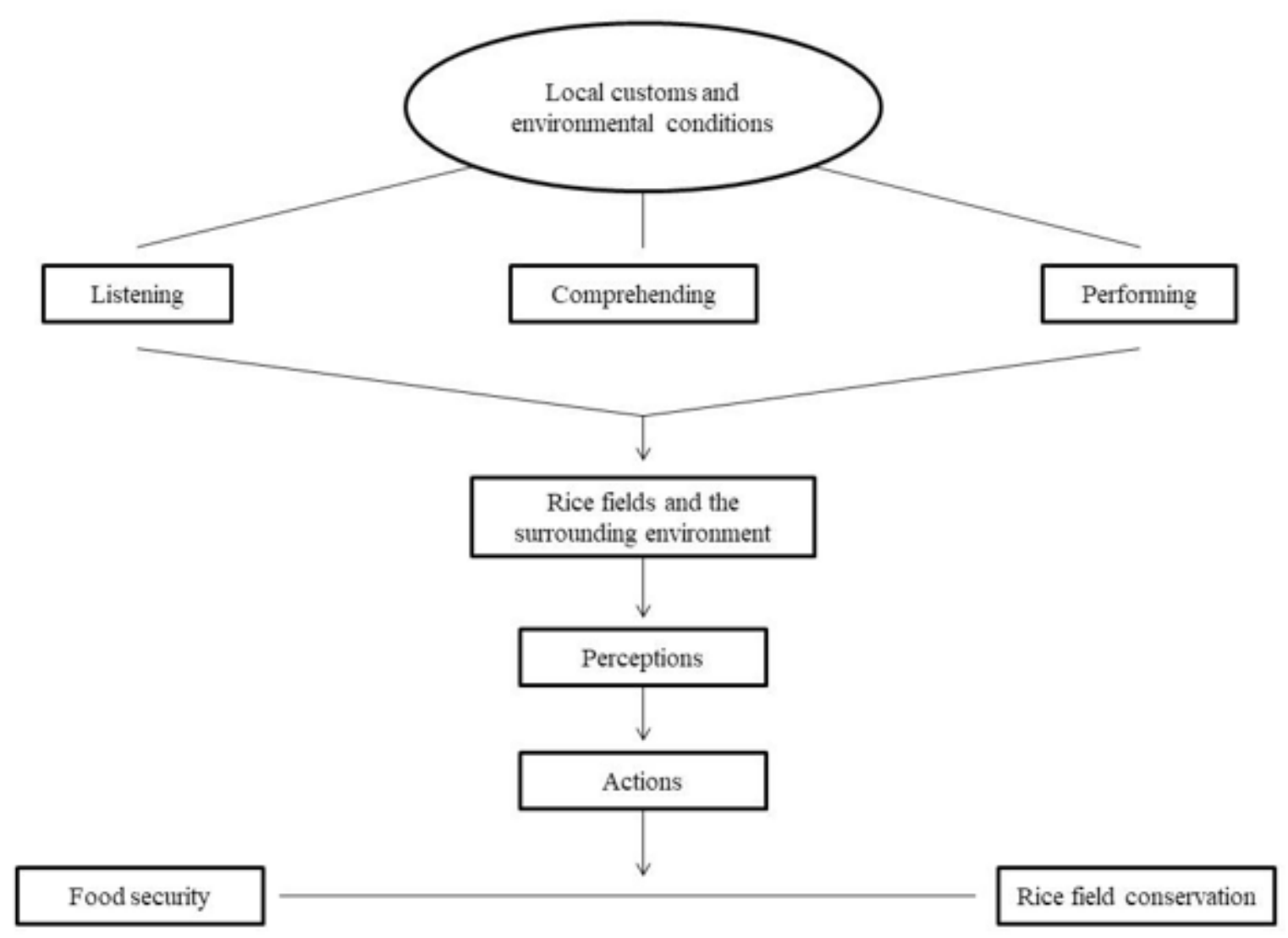

Source: Research analysis, 2020

Figure 1 Internalization of values to preserve rice fields in Semende Darat Tengah

is fulfilled by all parties. Although the aspect of performing usually occurs in the adolescent and adult groups, listening and comprehending have their parts also here. At first, it is in the older group and is gradually descended to the younger group. The starting point remains in the nuclear family, although in the process, it can take place coincidentally. The internalization in the family and activities in the community and other environments also goes at the same time. This goes on continuously in the framework of the prevailing custom. By doing these things, it is believed that the existing system can survive, although, in some respects, it seems contrary to the general assumptions. An example here is the habit of maintaining rice fields and planting rice once a year. All of these have reasons that can only be understood when the mechanism of listening, comprehending, and performing is applied in society.

The Semende people can maintain their agriculture characteristics too by planting in a once-a-year pattern and using local seeds. This is because there is internalization in the community, especially the messages from the ancestors that require the utilization of local seeds. Emically, this is based on the understanding that the weather and the availability of sunlight are pretty limited. So it is only rice from local varieties that can live there. Automatically, the use of chemical fertilizers is insignificant. That is because the local variety has better endurance, even though it needs a long period to be harvested. From an economic point of view, benefits from rice fields are not satisfactory because the fields with the onehectare area can only provide 2 tons of rice. This surely differs from other fields that already produce 6 tons per hectare. But the function of rice fields for the Semende people is not to seek economic wealth. It is for consumption in a year (subsystem economy). For other daily needs, the Semende people farm coffee and vegetables.

The environmental communication 
mechanism in Semende Darat Tengah is a combination of the rules in customary systems, the existence of strong institutions, all of which are based on knowledge and understanding of the physical conditions in Semende. The condition of the natural environment in the hills with high elevations is the reason for the presence of a custom order that is able to maintain the existence of the Semende people. This further strengthens the notion that environmental communication in rural communities cannot be separated from the local values they adhere to (Flor, 2004), including developing several rules of the game that they will mutually accept.

The final process of internalizing values is food security and rice field conservation. This differs from other commodities such as coffee. Coffee is indeed the most favorite crop in Semende. It has even become an icon to introduce Semende to people in other areas. But coffee is not a subsistence crop and for food security. It is more an economic crop for consumptive purposes.

The findings emphasize the fact that humans in understanding their environment are influenced by various factors. In the process, there will be classifying of the objects. In the context of the Semende Darat Tengah community (the same applies to other Semende people), a rice field is an object that has a special meaning. Rice fields are not just areas for crops with economic values but also an identity of the people (Yenrizal et al., 2015), So the cultivation of rice fields is following the provisions adopted by the Semende people that those who have Tunggu Tubang automatically own a field since Tunggu Tubing is a symbol of having rights to run the rice fields. Here, rice fields also symbolize food security. This is because, with a subsistence pattern, food availability for the community in one year is assured. On this basis, the Semende people are confident of claiming that none of their fellows will be in hunger because rice is available for a year.

The pattern of environmental communication in Semende Darat Tengah remains well preserved to this day. There is an aggregate between elements of the sociocultural system and the community's long-term needs. That is a communication mechanism that has a strong base (Flor, 2004). The interactions between the Semende people and their natural environment directed in a traditional order place the rice fields as a central part are conserved. Therefore, the basis of environmental communication is the cultural and value system created k (Flor, 2004).

Themodel of environmental communication based on the physical reality, also known as local wisdom, is surely a characteristic of rural communities. This can be seen in the comparison of the results of research on the Gedongkiwo people, who are able to make changes from various problems to become an empowered society (Jaya, 2020). Usually, the environmental communication process is built upon these aspects of the present environmental conditions. For instance, the case of the community in the Citarum River that shows how to improve the river by utilizing the presence of community leaders, majelis ta'lim (a forum to learn about Islam), religious institutions, or other elements is concrete evidence of the process (Bakti et al., 2017). In the Semende community, this also appears. Yet, it is not in the context of saving the environment. It is more about social realities that have been established and well preserved.

The ability to persevere the primary patterns and strengthen environmental communication models that have developed has been a characteristic of the Semende Darat Tengah community. In other areas in Indonesia, such as Bedugul village in Bali (Sujarwo, 2019), Badui in Banten (Syarbini, 2015), and Kampung Naga in West Java (Qodariah \& Armiyati, 2015), a similar model of communication is also found. The community group tends to restrict relations with outsiders in order to maintain their traditional system of life. Traditional mechanisms are also carried out in daily life, such as the use of agricultural tools or local seeds in farming.

However, this is different from the community in Semende Darat Tengah. On the one side, they follow the development and welcome external influence. But local provisions remain well employed. The characteristic of the Semende Darat Tengah community is that they have hereditary views. Although they remain adaptive to the world's developments, their traditional and social institutions constantly maintain the continuity of this communication pattern. Even though, to some extent, the land seems "abandoned," its existence is still irreplaceable. An interesting finding in the context of communication ethnography is 
the endurance of traditional meanings and institutions as a form of food security, though they are not closed communities.

The conditions above indicate an understanding of the constitutive meaning in the context of environmental communication (Cox, 2012). The environmental communication mechanism takes place following the context of the needs and harmony of the relationship with the natural environment. The meanings of the environment have still existed even though changes last to occur.

\section{CONCLUSION}

Based on the purpose of this study, it seems that the environmental communication mechanism in rural communities, especially in Semende Darat Tengah, takes place in the context of harmony with the changing times. But it does not replace the fundamental structure. Compliance with the prevailing customary system as well as knowledge and understanding of the natural conditions in the area are the key elements. The internalization process occurs in the mechanism of listening, comprehending, and performing, both for the nuclear family, neighborhood, the surrounding community, and the customary institutions. Perceptions about rice fields and the environment do not appear automatically. These go through numerous stages that are already set in the community and have been internalized in the nuclear family as the initial step. Family and customary institutions become the most dominant elements in shaping the meaning and perception of rice fields. Events of environmental communication transpire in a natural atmosphere in line with the socio-cultural conditions predominating in society. Communication takes place in both public and private areas, such as in the family. Knowledge about the environment is always inherited in various ways that apply to the existing customary rule.

The recommendation that can be conveyed from this research, especially to traditional rural communities, the people of Semende Darat Tengah in this case, is that the meaning of the environment that has been established so far must be continuously communicated to the next generation, even though time is changing. Decision-makers should also understand well the characteristics of the community before implementing a policy. Academically, this research suggests that a thoroughly ethical and emic understanding is essentially required in studying the characteristics of society, especially in enriching investigations on environmental communication. Not all the changing society will also replace the meaning of the actual environmental conditions.

\section{REFERENCES}

Arif, S., Isdijoso, W., Fatah, A. R., \& Tamyis, A. R. (2020). Tinjauan strategis ketahanan pangan dan gizi di Indonesia: Informasi Terkini 2019-2020. Smeru Research Institute.

Arifin, Z., Delfi, M., \& Pujiraharjo, S. (2017). Tunggu Tubang, marginalisasi perempuan Semende. Musawa, 16(2), 235.

Ashari, N. (2016). Tinjauan tentang Alih fungsi lahan sawah ke non sawah dan dampaknya di Pulau Jawa. Forum Penelitian Agro Ekonomi, 21(2), 83. https://doi. org/10.21082/fae.v21n2.2003.83-98

Bakti, I., Hafiar, H., \& Budiana, H. R. (2017). Environmental communication based on local wisdom in anticipation of Citarum flood. MIMBAR, Jurnal Sosial Dan Pembangunan, 33(1), 208. https://doi. org/10.29313/mimbar.v33i1.2281

BPS. (2020). Luas panen dan produksi padi di Indonesia 2019. Badan Pusat Statistik.

BPS, M. E. (2021). Muara Enim dalam Angka 2021 (p. 439). BPS Muara Enim.

Cox, R. (2012). Study and practice of Environmental Communication. Environmental Communication and the Public Sphere, 1, 11-38. http://www. sagepub.com/upm-data/47777_ch_1.pdf

Creswell, J. W. (2007). Qualitative inquiry and research design choosing among five approaches 2nd edition. University of Nebraska.

Djoni, Suprianto, \& Cahrial, E. (2016). Kajian alih fungsi lahan pertanian tanaman pangan di Kota Tasikmalaya. Jurnal Mimbar Agribisnis, 1(3), 233-244.

Feintrenie, L., Schwarze, S., \& Levang, P. (2010). Are local people conservationists? analysis of transition dynamics from 
agroforests to monoculture plantations in Indonesia. Ecology and Society, 15(4). https://doi.org/10.5751/ES-03870-150437

Flor, A. G. (2004). Environmental communication: principles, approaches and strategies of communication applied to environmental management by. UP Open University. https://doi. org/10.1080/15330150590934480

Iskandar, J., \& Iskandar, B. S. (2017). Local knowledge of the baduy community of south Banten (Indonesia) on the traditional landscapes. Biodiversitas, 18(3), 928-938. https://doi.org/10.13057/biodiv/d180309

Jaya, P. H. I. (2020). Media sosial, komunikasi pembangunan, dan munculnya kelompokkelompok berdaya. Jurnal Kajian Komunikasi, 8(2), $166 . \quad$ https://doi. org/10.24198/jkk.v8i2.16469

Kusumastuti,A. C., M. Kolopaking, L., \& Barus, B. (2018). Faktor yang mempengaruhi alih fungsi lahan pertanian pangan di Kabupaten Pandeglang. Sodality: Jurnal Sosiologi Pedesaan, 6(2), 131-136. https:// doi.org/https://doi.org/10.22500/sodality. v6i2.23234

Mahdi, I. (2016). Konsep gender pada masyarakat adat suku Semendo Kabupaten Muara Enim (Studi Kasus Pada Adat Tunggu Tubang). Hawa, 1(1). https://doi. org/10.29300/hawapsga.vli1.2232

Mahmuddin. (2013). Paradigma pembangunan pertanian: pertanian berkelanjutan berbasis petani dalam perspektif sosiologis. Jurnal Sosiologi, 3(3), 59-76.

Qodariah, L., \& Armiyati, L. (2015). Nilai-nilai kearifan lokal masyarakat adat Kampung Naga sebagai alternatif sumber belajar. SOCIA: Jurnal Ilmu-Ilmu Sosial, 10(1), 10-20. https://doi.org/10.21831/socia. v10i1.5338

Rambo, A. T. (1983). Conceptual approaches to human ecology conceptual approaches to human ecology (Issue 14). East-West Center.

Rinardi, H., Masruroh, N. N., Maulany, N. N., \& Rochwulaningsih, Y. (2019). Dampak revolusi hijau dan modernisasi teknologi pertanian: studi kasus pada budi daya pertanian bawang merah di Kabupaten Brebes. Jurnal Sejarah Citra Lekha, 4(2), 125-136. https://doi.org/10.14710/jscl. v4i2.21936

Sujarwo, W. (2019). Bedugul portrait: an ethnoecological study of the relationship between man and the environment. Jurnal Wilayah Dan Lingkungan, 7(1), 52. https:// doi.org/10.14710/jwl.7.1.52-62

Syarbini, A. (2015). Kearifan lokal Baduy Banten. Refleksi, 14(1), 55-74. https://doi. org/10.15408/ref.v14i1.9577

Velinda, A., Wilodati, W., \& Kosasih, A. (2018). Tunggu Tubang dalam pembagian harta warisan pada masyarakat Suku Semende. Sosietas, 7(2), 420-423. https://doi. org/10.17509/sosietas.v7i2.10360

Wijaksono, R. R., \& Navastana, A. M. (2012). Pengendalian perubahan pemanfaatan lahan pertanian tanaman pangan di Kabupaten Banyuasin , Provinsi Sumatera Selatan (Untuk Mendukung Program Lumbung Pangan Nasional ). Tektnik ITS, 1(1), 52-57.

Yenrizal, Rahmat, A., Bajari, A., \& Iskandar, J. (2015). Makna simbolik sawah di masyarakat pedesaan, tinjauan komunikasi lingkungan pada masyarakat Semende Darat Tengah Kabupaten Muara EnimSumatera Selatan. Kawistara, 5(3), 287-297. https://doi.org/https://doi. org/10.22146/kawistara.10057

Yenrizal, Y. (2017). Penyebaran nilainilai lingkungan di masyarakat petani pedesaan (studi etnografi komunikasi pada masyarakat desa Tenam Bungkuk, Semende Darat Kabupaten Muara Enim, Provinsi Sumatera Selatan). Jurnal Studi Sosial Dan Politik, 1(2), 179-193. https:// doi.org/10.19109/jssp.v1i2.4042

Yenrizal, Y. (2018). Makna lingkungan hidup di masa sriwijaya: analisis isi pada prasasti talang tuwo. Jurnal ASPIKOM, 3(5), 833. https://doi.org/10.24329/aspikom.v3i5.302

Yudiarini, N. (2011). Perubahan pertanian subsisten tradisional ke pertanian komersial. DwijenAGRO, 2(1), 1-8. https://doi.org/https://doi.org/10.46650/ dwijenagro.2.1.271.\%25p

Zacks, J. M. (2019). Introduction to events and objects in perception, language, and communication. Baltic International Yearbook of Cognition, Logic and Communication, 13(1). https://doi. org/10.4148/1944-3676.1123 